\title{
アユの成長に及ぼす溶存酸素の影響について
}

\author{
千葉健治
}

(1987 年 10 月 15 日受理)

\section{The Effect of Dissolved Oxygen on the Growth of Young Ayu}

\author{
Kenji Chiba*
}

\begin{abstract}
Experiments were carried out to examine the effect of dissolved oxygen on the growth of young ayu (body weight $2.0-8.0 \mathrm{~g}$ ).

Fish were reared for 8 days in 5 different tanks. Each of these tanks had a volume of 16 litres. These tanks were continuously supplied with freshwater having different dissolved oxygen concentrations. Reduced oxygen concentrations were maintained by bubbling nitrogen gas through the inflowing water. During the experiments water temperature ranged between 24 and $25^{\circ} \mathrm{C}$. Fish were fed three times a day with commercially a vailable, crumbled pellet for young ayu.

Fish showed almost even levels of growth rate and feed conversion efficiency in water of $45 \%$ or more in percent oxygen saturation, while below $45 \%$ these levels decreased with the reduction of oxygen concentration. Growth rates and feed conversion efficiencies at the oxygen concentration. Growth rates and feed conversion efficiencies at the oxygen concentrations of 27 and $35 \%$ in percent oxygen saturation were about $1 / 2$ and $1 / 2-2 / 3$ of those at the concentration of over $45 \%$, respectively. However, the feeding rate reduced with the decrease in dissolved oxygen within the whole range of oxygen examined.
\end{abstract}

アニ Plecoglossus altivelis は淡水魚のうちでも重要な 盖殖対象魚であり，通常流水池で飼育される。流水式着 殖の場合, 養魚池への注水量が飼育可能量中善魚成績な どを大きく左右する。流隶池中の溶存酸素量は注水の溶 存酸素量と流量すなわち酸素の供給量と, 铜育されてい る魚によるその消費量によって大きく影響され様々な值 を示す。これが飼育環境要因として重要な役割を果たし 養魚成績にかかわるるのと考えられる。そこで本研究に 批いては, 環境水の溶存酸素がフ二の撕䬣・成長にどの よらな影響を与え、更には差魚成績にどのように関連す るかを明らかにすることを目的として実験を行った。

\section{実 駼 方 法}

昭和 49 年 3 月静岡県浜名湖で採捕後, 引き続き浜名 湖畔にある東京大学水産実験所の水槽で飼育したて二稚 魚（体重 $2.0 \sim 8.0 \mathrm{~g}$ )を実験に供した。

飼育装置は前報1)のーダイの飼育に用いたものと同様 である。すなわち、エアストーンを入れ十分に通気を行 っている眝水槽 $(36 \times 52 \times 28 \mathrm{~cm})$ 加水を直径 $6 \mathrm{~cm}$ 高 さ $120 \mathrm{~cm}$ の塩化ビニール製のパイプに導き，底から窒 素ガスを通気する。このパイプに流入する水量と窒素ガ
スの通気量を調節することにより，パイプの底から流出 する水の溶存酸素量を種々の濃度に設定することが可能 となる。この溶存酸素量の調節された水を密閉された飼 育水槽に導き，この中でアユを飼育する。この水槽は塩 化ビニール製で，供試魚の行動を観察し易い上うに上面 および 1 側面が透明にしてある。大きさは $20 \times 20 \times 40$ $\mathrm{cm}$ で蓋と水槽本体との間に $2 \mathrm{~mm}$ 厚のゴム板を摤み, ボルト及びナットで締め水密となるようにした。蓋には 直径 $3 \mathrm{~cm}$ の孔を開けてあり，常時はゴム栓をしておき， 給䬲時にはゴム栓を除いて眲を与えた。同様の装置を5 組用意し，種々の溶存酸菜量の下でアニの飼育を行っ た。

1 回の実験の飼育期間は 8 日とし, それぞれの水槽に 20 尾の供試魚を収容した。供試魚の全長・体重を測定 の後各飼育水槽に収容し，1 日無給䬲で所定の溶存酸素 量のもとに和き，翌日より6日間給慨を行い，更に1日 絶食させた後取り揚げ全長・体重を測定した。慨はオリ エンタル醅母会社製のアニ用クランブル2号を用い，1 日 3 回, それぞれ 9 時, 13 時及び 17 時に給飭を行っ た。供試魚が積極的な掑䬲行動を示している間のみ䬣を 与え，摄慨が不活発になった时に給慨を終了した。クラ

* 東京大学農学部附属水産実験所 (Fisheries Laboratory, The University of Tokyo, Maisaka, Shizuoka, 34-102, Japan). 
ンブルは一定量を容器にいれておき，1日3回の給䬣を 終えた後再度これを秤量して給䬣量を算出した。フユは このような小型の密閉水槽中でも比較的活発に掑慨す る。水槽の底に落ちた慨む多少は摄るが，すべてを掑り 尽寸ことはなく知回多少の残飰の出るのを避けることは 出来なかっだ。したがって，給䫀量は搨慨量と等しくは ない。しかし，掑餌率の算出にあたっては給慨量を掑慨 量と見なした。注水量は水槽ごとに多少の差はあるが、 ずれ电每分 $2.0 \sim 2.51$ 口籁团内に古った。溶存酸菜量に ついては，各水槽の注氷部，排水部及び水槽中央で測定 したところ，いずれの水槽でも排水部及び中央部の溶存 酸素量には殆ど差がなく、注承部では飽和度で $2 \%$ 程度 高い值を示した。そこで非水部の酸素量をてり水槽の溶 存酸素量とすることとした。溶存酸素: 每日午前 9 時給 餌直前に各水槽の排水部で測定し，飼育期間中の平均值 をもってその水槽の溶存酸素量とした。

同様の実驗を 11 回繰り返した。

\section{結果}

実験実施時期、実駼期間中の水温変動範西及び平均值 をTable 1 に示した。使用した淡水は東京大学水産実䍄 所構内の深さ $300 \mathrm{~m}$ の井戸から揚水されたものでこの 井水は周年 $24.8^{\circ} \mathrm{C}$ 程度のほ注一定の水温を示す。この ため実験中の各水槽の水温は実駼実施時期にかか水らず $24.0 \sim 25.0^{\circ} \mathrm{C}$ の範囲内にあった。

11 回繰り返された実験の結果については Table 2 に 示した。各水槽への供試魚の收容は 20 尾を原則とした が，実験によっては途中死亡魚のでる場合があった。こ の淙には飼育期間中供試魚の体重順位は变初らない。の と仮定し，実駼開始時，終了時扰上び死亡魚の体重か：ら 死亡魚に相当する個体を開始時の供試魚から除いて平均 体重等の計算を斿こなった。。ま，日間掑慨率及び飭料

Table 1. Period of the experiments and water temperature

\begin{tabular}{|c|c|c|c|}
\hline \multirow{2}{*}{$\begin{array}{l}\text { Test } \\
\text { No. }\end{array}$} & \multirow{2}{*}{ Test period } & \multicolumn{2}{|c|}{$\begin{array}{l}\text { Water temperature } \\
\left({ }^{\circ} \mathrm{C}\right)\end{array}$} \\
\hline & & Mean & Range \\
\hline 1 & 74 May $13-20$ & 24.32 & $24.5-24.2$ \\
\hline 2 & '74 May 21-28 & 24.43 & $24.5-24.4$ \\
\hline 3 & '74 May 29-Jun. 5 & 24.43 & $24.5-24.4$ \\
\hline 4 & 74 Jun. 6-13 & 24.48 & $24.7-24.2$ \\
\hline 5 & '74 Jun. 14-21 & 24.57 & $24.8-24.4$ \\
\hline 6 & 74 Jun. $21-28$ & 24.66 & $24.7-24.6$ \\
\hline 7 & '74 Jun. 29-Jul 6 & 24.72 & $24.9-24.6$ \\
\hline 8 & '74 Jul. 7-14 & 24.72 & $25.0-24.5$ \\
\hline 9 & '74 Jul. 15-22 & 24.88 & $25.0-24.6$ \\
\hline 10 & "74 Jul. 23-30 & 24.85 & $25.0-24.7$ \\
\hline 11 & '74 Jul. 31-7 & 24.25 & $24.8-24.0$ \\
\hline
\end{tabular}

効率の算出にあたっては全給䭒量を給期日数及び開始時 と終了時の総魚体重の平均值で除し，こ机に 100 を乘し て求めた。また，日々各供試魚は均等に損慨したものと して死亡魚による摂䬣量を補正した。

溶存酸素之增重率，給餉率及び䬣料効率との関係をみ

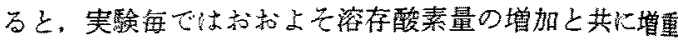

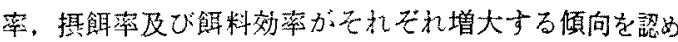
ることができるしかしながら，それそれ值は同様の 酸素量に乎かか加らず大きく変動する。このよらな変動 は初期体重や実䀫実施時期の違いなどにもよるものと思

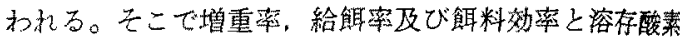
量との関係をより明らかにするため，各実験每に溶存酸 素量が飽和度 $65 \%$ 以上の水槽の增重率，給慨率及び䬣 料効率の乞れを゙れを相対值 100 として，他の水槽での增

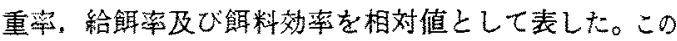
際，飽和度 $65 \%$ 以上の水槽が複数の場合汇はその平均 值を相対値 100 とした。それらの相対値々酸素螕和度と の関倸を Fig. 1 3 に示した。更に各実験を平均溶存酸 素量によって $20 \%$ 以上 $30 \%$ 末满， $30 \%$ 以上 $40 \%$ 末満， ‥の上万に 10\% 每に区分し，それぞれの区分内の各 相対値の平均値並ひにその $95 \%$ 信頼限界を算出し。こ れをそれぞれの区分内の各実䮲の平均溶存酸素量の平均 值に対してプロットして Fig. 1 3 に併せて示した。こ のような相対値で示してもなお同様の酸素飽和度に対し それぞれの相対值は比較的大きな変動を示す。しかしな がら，いずれの項目でを，酸素量の増大と共に低酸素㖪 では急激に增加，中程度以上の酸素域ではほ仿一㥞の值 を示すか，もしくは緩やか心增加する傾向を認めること ができる。なお一層この㑯向を明確に把握するために， 各 $10 \%$ 酸素飽和度区分の相対値の平均値について，そ れぞれ裂合う3 平均値の移動平均を求め。これらを通る 滑らかな曲線を描きそれぞれの図中に示した。

この曲線を考慮すれば、Fig. 1 及び 3 に示した增重草 並び纪餌料效率は，枹和度 $45 \%$ 以下では酸素量の低下 と共にそれぞれ急激な低下を示し，45\%以上ではいず れも $55 \%$ に最高值がありそれ以上ではやや低下する㥀 向が認められる。それぞれの平均值の信頼限界をあわ地 て考慮すれば，酸素飽和度 27\% 及び 35\%では增重率， 飭料効率共に有意な低下を示したと考えることができる が，45\%以上ではそれぞれの平均値の差は有意である

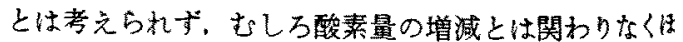
ぼ一様な值を示すと考克るのが妥当であろ5。すなか ち，增重率で性酸素䭒和度 $45 \%$ 以上では酸素量とは等

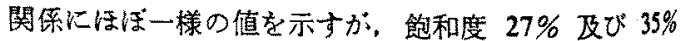
では相対值はそれぞれ 40,55を示し，酸素飽和度 $45 \%$ 以上の場合の $1 / 2$ 程度の增重しか示さなかったことにな る。また，慨料効率については酸素飽和度 $45 \%$ 以上て 
Table 2. Result of experiment

\begin{tabular}{|c|c|c|c|c|c|c|c|c|c|c|c|}
\hline $\begin{array}{l}\text { Test } \\
\text { No. }\end{array}$ & $\begin{array}{l}\text { Tank } \\
\text { No. }\end{array}$ & $\begin{array}{l}\mathrm{DC} \\
\text { Mean }\end{array}$ & $\begin{array}{l}\text { Range } \\
\text { Rang }\end{array}$ & $\begin{array}{l}\text { No. of } \\
\text { Fish }\end{array}$ & Start & \multicolumn{2}{|c|}{$\begin{array}{l}\text { Body Weight (g) } \\
\text { SD End }\end{array}$} & $\mathrm{SD}$ & $\begin{array}{c}\text { Growth } \\
\text { Rate } \\
(\%)\end{array}$ & $\begin{array}{c}\text { Feeding } \\
\text { Rate } \\
(0)\end{array}$ & $\begin{array}{l}\text { Feed } \\
\text { Con. } \\
\text { Efficiency } \\
(0)\end{array}$ \\
\hline \multirow{5}{*}{1} & 1 & 37.4 & $43.7-31.2$ & 20 & 2.28 & 0.52 & 2.42 & 0.58 & 6.14 & 4.04 & 30.43 \\
\hline & 2 & 38.7 & $46.5-34.9$ & 20 & 2.34 & 0.71 & 2.46 & 0.73 & 5.13 & 3.98 & 25.81 \\
\hline & 3 & 55.3 & $63.9-50.2$ & 20 & 2.18 & 0.57 & 2.38 & 0.53 & 9.17 & 4.64 & 39.68 \\
\hline & 4 & 65.5 & $65.6-70.1$ & 20 & 2.26 & 0.57 & 2.48 & 0.64 & 9.73 & 4.43 & 44.00 \\
\hline & 5 & $73.9 k$ & $85.2-67.2$ & 20 & 2.27 & 0.53 & 2.42 & 0.60 & 6.61 & 4.20 & 33.70 \\
\hline \multirow{5}{*}{2} & 1 & 32.3 & $34.9-29.5$ & 20 & 2.42 & 0.58 & 2.52 & 0.56 & 4.13 & 4.13 & 16.66 \\
\hline & 2 & 34.4 & $36.6-32.4$ & 20 & 2.46 & 0.73 & 2.59 & 0.82 & 5.28 & 3.77 & 23.42 \\
\hline & 3 & 45.0 & $46.6-41.2$ & 20 & 2.38 & 0.53 & 2.54 & 0.60 & 6.72 & 4.74 & 26.44 \\
\hline & 4 & 65.1 & $72.4-57.7$ & 20 & 2.48 & 0.64 & 2.60 & 0.66 & 4.84 & 4.34 & 19.38 \\
\hline & 5 & 74.1 & $81.6-62.2$ & 20 & 2.42 & 0.60 & 2.59 & 0.71 & 7.02 & 5.23 & 22.37 \\
\hline \multirow{5}{*}{3} & 1 & 35.3 & $38.8-31.4$ & 20 & 2.52 & 0.66 & 2.59 & 0.67 & 2.78 & 3.54 & 13.08 \\
\hline & 2 & 43.8 & $68.8-31.2$ & 20 & 2.57 & 0.58 & 2.72 & 0.66 & 5.84 & 3.85 & 25.27 \\
\hline & 3 & 53.1 & $67.9-45.5$ & 20 & 2.48 & 0.66 & 2.63 & 0.75 & 6.05 & 3.79 & 25.42 \\
\hline & 4 & 73.2 & $77.9-69.6$ & 20 & 2.67 & 0.85 & 2.83 & 0.98 & 5.99 & 4.53 & 22.07 \\
\hline & 5 & 87.9 & $93.4-81.9$ & 20 & 2.59 & 0.61 & 2.72 & 0.67 & 5.02 & 5.12 & 15.72 \\
\hline \multirow{5}{*}{4} & 1 & 30.9 & $34.2-28.1$ & 10 & 2.73 & 0.82 & 2.75 & 0.85 & 0.73 & 7.39 & 0.73 \\
\hline & 2 & 33.4 & $43.0-21.9$ & 18 & 2.83 & 0.06 & 2.93 & 0.65 & 3.53 & 5.60 & 11.11 \\
\hline & 3 & 47.8 & $54.8-35.3$ & 19 & 2.56 & 0.71 & 2.80 & 0.85 & 9.38 & 5.95 & 26.26 \\
\hline & 4 & 63.4 & $69.9-51.9$ & 19 & 2.72 & 0.89 & 2.91 & 1.02 & 6.99 & 6.29 & 17.95 \\
\hline & 5 & 73.9 & $85.2-59.6$ & 18 & 2.74 & 0.69 & 2.97 & 0.77 & 8.39 & 7.61 & 18.22 \\
\hline \multirow{5}{*}{5} & 1 & 32.5 & $43.0-24.6$ & 20 & 3.10 & 0.86 & 2.93 & 0.85 & -5.48 & 2.55 & -36.84 \\
\hline & 2 & 35.9 & $41.4-24.6$ & 20 & 2.77 & 0.65 & 2.89 & 0.76 & 4.33 & 3.59 & 20.17 \\
\hline & 3 & 48.4 & $53.4-37.8$ & 20 & 3.01 & 0.86 & 3.27 & 0.95 & 8.64 & 4.72 & 24.47 \\
\hline & 4 & 73.7 & $82.4-68.1$ & 20 & 3.36 & 0.92 & 3.69 & 1.14 & 9.82 & 5.63 & 29.07 \\
\hline & 5 & 78.6 & $82.9-68.9$ & 20 & 3.19 & 0.77 & 3.37 & 0.80 & 5.64 & 5.67 & 16.13 \\
\hline & 1 & 27.5 & $23.6-17.2$ & 19 & 2.90 & 0.87 & 2.98 & 0.84 & 2.76 & 4.68 & 12.40 \\
\hline & 2 & 27.0 & $29.6-24.8$ & 20 & 2.89 & 0.76 & 2.95 & 0.79 & 2.08 & 4.92 & 9.15 \\
\hline 6 & 3 & 35.8 & $40.2-29.4$ & 18 & 3.34 & 0.99 & 3.48 & 1.11 & 4.19 & 6.31 & 12.63 \\
\hline & 4 & 54.0 & $56.3-50.1$ & 20 & 3.69 & 1.14 & 3.90 & 1.32 & 5.69 & 6.45 & 17.65 \\
\hline & 5 & 65.0 & $67.8-61.6$ & 20 & 3.37 & 0.80 & 3.57 & 0.93 & 5.93 & 7.88 & 15.47 \\
\hline & 1 & - & - & - & - & - & - & - & - & - & - \\
\hline & 2 & 28.8 & $34.8-25.9$ & 19 & 3.52 & 0.97 & 3.54 & 0.96 & 0.57 & 3.99 & 1.88 \\
\hline 7 & 3 & 39.4 & $54.1-43.4$ & 16 & 3.48 & 1.13 & 3.72 & 1.21 & 6.90 & 5.34 & 21.91 \\
\hline & 4 & 65.9 & $69.8-63.9$ & 16 & 3.43 & 1.07 & 3.71 & 1.74 & 8.16 & 5.23 & 26.74 \\
\hline & 5 & - & - & - & - & - & - & - & - & - & - \\
\hline & 1 & 25.9 & $28.8-22.5$ & 18 & 3.59 & 0.53 & 3.96 & 0.65 & 10.31 & 5.85 & 28.63 \\
\hline & 2 & 31.7 & $55.8-25.3$ & 20 & 3.85 & 0.68 & 4.23 & 0.76 & 9.87 & 5.31 & 31.43 \\
\hline 8 & 3 & 31.9 & $36.7-28.4$ & 20 & 3.76 & 0.68 & 4.26 & 0.83 & 13.30 & 6.18 & 35.84 \\
\hline & 4 & 58.3 & $62.3-54.8$ & 19 & 3.81 & 0.79 & 4.54 & 1.02 & 19.16 & 6.85 & 46.80 \\
\hline & 5 & 65.0 & $67.4-59.4$ & 20 & 3.91 & 0.75 & 4.54 & 1.04 & 16.11 & 8.72 & 30.81 \\
\hline & 1 & 26.6 & $29.2-23.9$ & 18 & 4.19 & 0.74 & 4.29 & 0.77 & 2.39 & 6.63 & 9.60 \\
\hline & 2 & 35.0 & $43.0-29.2$ & 20 & 4.23 & 0.76 & 4.61 & 0.89 & 8.98 & 7.02 & 25.59 \\
\hline 9 & 3 & 37.3 & $41.5-29.2$ & 20 & 4.49 & 0.89 & 5.01 & 1.08 & 11.58 & 7.54 & 31.07 \\
\hline & 4 & 70.9 & $76.5-58.2$ & 20 & 4.80 & 1.03 & 5.43 & 1.28 & 13.13 & 7.92 & 33.68 \\
\hline & 5 & 66.7 & $70.3-64.8$ & 13 & 4.60 & 1.03 & 5.64 & 0.93 & 22.61 & 7.74 & 35.25 \\
\hline & 1 & 27.3 & $29.3-24.9$ & 15 & 4.57 & 1.02 & 4.84 & 1.11 & 5.91 & 7.31 & 13.29 \\
\hline & 2 & 31.7 & $38.6-29.2$ & 16 & 4.89 & 0.62 & 5.11 & 0.84 & 4.50 & 7.29 & 10.53 \\
\hline 10 & 3 & 36.8 & $43.3-33.1$ & 12 & 5.41 & 0.91 & 5.66 & 1.11 & 4.62 & 10.09 & 8.89 \\
\hline & 4 & 74.0 & $79.2-69.8$ & 16 & 5.28 & 1.15 & 5.69 & 1.19 & 7.77 & 8.69 & 15.23 \\
\hline & 5 & 65.0 & $67.2-58.0$ & 15 & 5.36 & 1.39 & 5.94 & 1.68 & 11.91 & 10.74 & 16.80 \\
\hline & 1 & 27.1 & $31.7-24.8$ & 11 & 5.30 & 0.90 & 5.61 & 1.10 & 5.85 & 7.15 & 13.60 \\
\hline & 2 & 30.9 & $33.2-29.5$ & 13 & 5.32 & 0.79 & 5.73 & 0.80 & 7.71 & 6.20 & 21.01 \\
\hline 11 & 3 & 38.9 & $41.2-34.8$ & 10 & 6.07 & 1.19 & 6.60 & 1.29 & 8.73 & 7.50 & 19.41 \\
\hline & 4 & - & - & - & - & - & - & - & - & - & - \\
\hline & 5 & 72.7 & $77.3-67.8$ & 11 & 6.75 & 1.12 & 7.46 & 1.49 & 10.52 & 8.76 & 20.26 \\
\hline
\end{tabular}

Growth rate was calculated from the initial and final mean body weight. Feeding rate was calculated as follows: Average amount of feed consumed for one day was devided by average value of initial and final total boday weight and multiplied by 100 . Feed conversion efficiency cuiculated as the perentage of total weight gain to anount of given feed. 


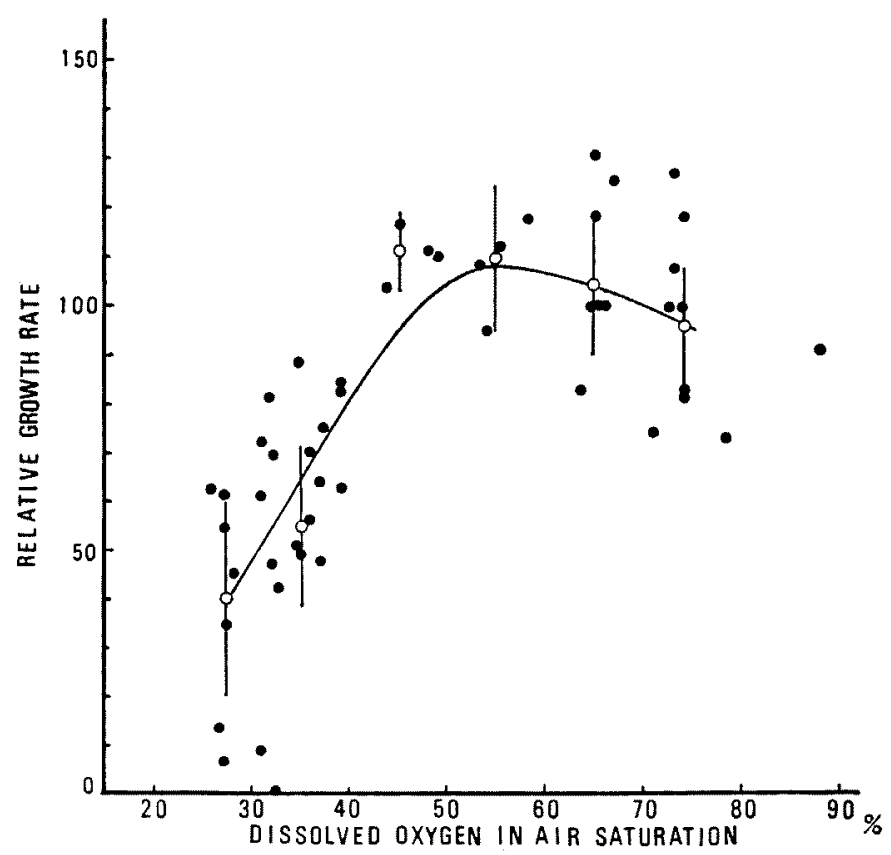

Fig. 1. Relationship between the relative rate of growth and the level of dissolved oxygen in percent saturation.

An open circle with vertical lines shows an average value and its $95 \%$ confidence intervals. The curve was obtained by the moving average method running three average values in turn.

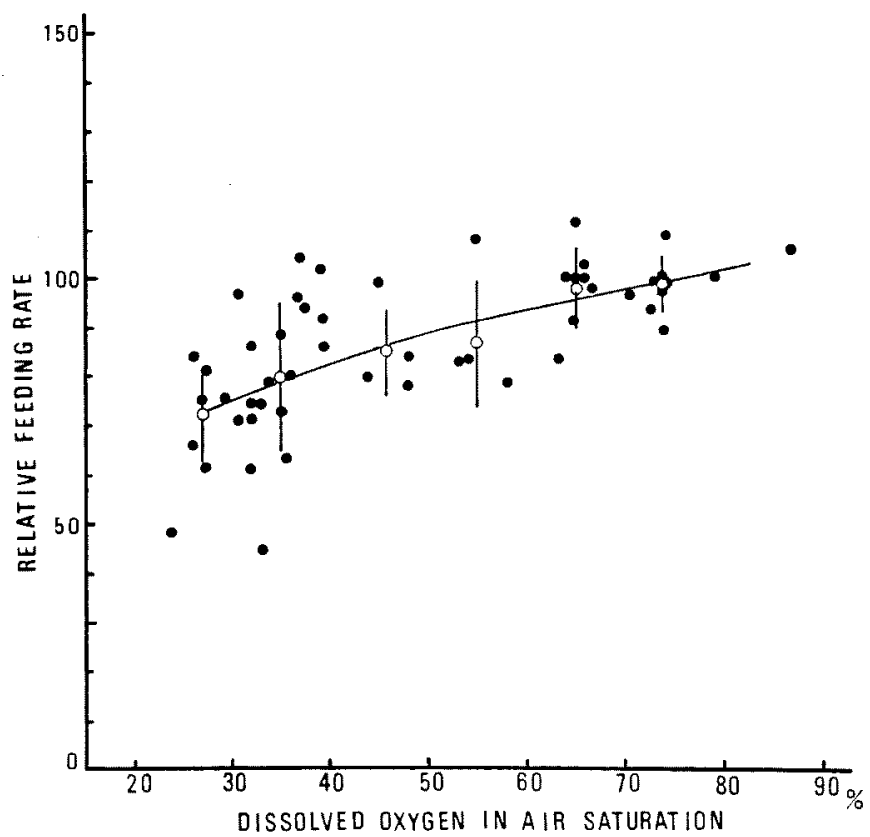

Fig. 2. Relationship between the relative rate of feeding and the level of dissolved oxygen in percent saturation.

An open circle with vertical lines shows an average value and its $95 \%$ confidence intervals. The curve was obtained by the moving average method running three average values in turn. 


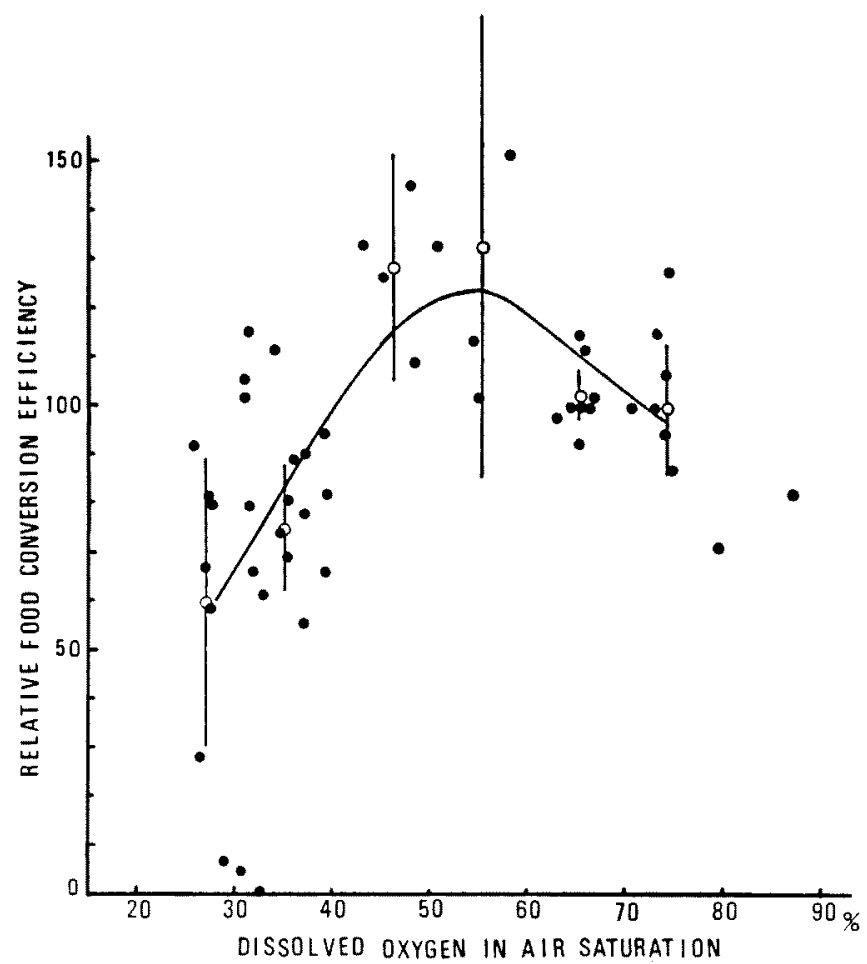

Fig. 3. Relationship between the relative efficiency of feed conversion and the level of dissolved oxygen in percent saturation.

An open circle with vertical lines shows an average value and its $95 \%$ confidence intervals. The curve was obtained by the moving average method running three average values in turn.

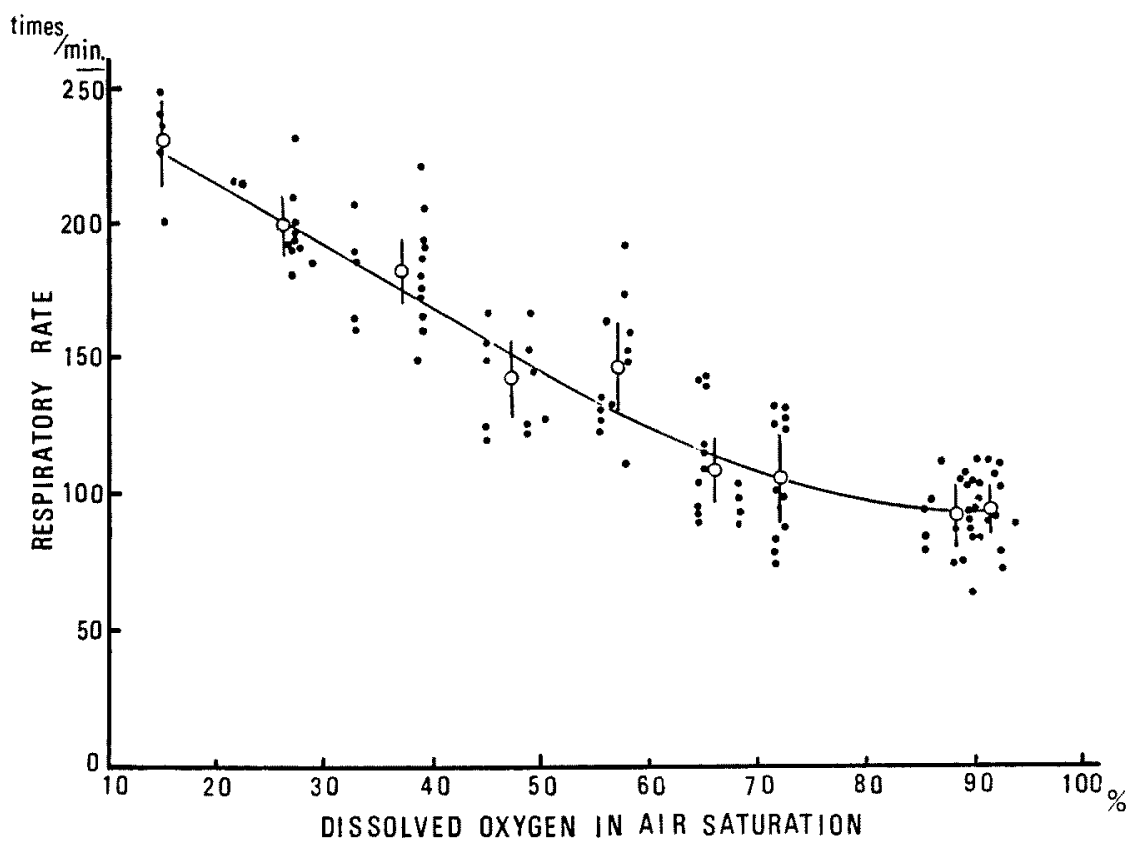

Fig. 4. Relationship between the respiratory rate and the level of dissolved oxygen in percent saturation.

An open circle with vertical lines shows an average value and its $95 \%$ confidence intervals. The curve was obt $s$ ined by the moving average method running three average values in turn. 
は相対值は 100 130 の篹囲にあるが飽和度 $27 \%$ 及び $35 \%$ では相対值はそれでれ 55 及び 75 を示し，飽和度 $45 \%$ 以上の場合に較べ $1 / 2 \sim 2 / 3$ 程度の效率であっだ。

一方，Fig. 2 の摂餌率についてみると，溶存酸素の低

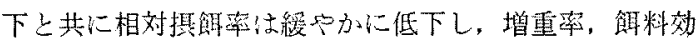
率の上うに中程度の酸素量で最高値を示すことはなかっ た。給慨時の観察でも酸素飽和度 23.2 23.5\% では殆ど

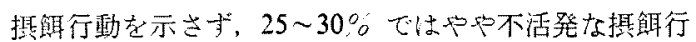
動が認められ，40\% 以上では積極的な搑咱活動が観察 された。他の頁目で低い值を示した酸素飽和度 $27 \%$ 品 及

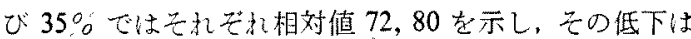
他の項目程著しくはなかった。このように Fig. 2 に示し た相対摄䭒率と酸素飽和度の関原は必ずしも低酸素飽和 度で著しく低い相対摆慨率とはなっていない。これは，

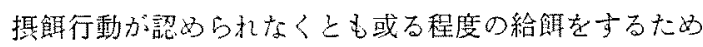

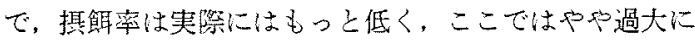
見ているものと考克て上からら。

更に，䬲料効率の場合，その変動は他の項目に比べて 大きい。これは主として給䬲量と摂䫀量とが一致せず残 䭒を生じ，しかもこの残䭒量が各承槽で一様でなく、こ の給䬣量を基汇䭒料効率を算出したたると考劣られる。 また他の項目之異なり低酸素域のみならず高酸素域でも 効率の低下が認好られる。低酸素域での低い飭料効率は 椇飭率の場合と同様の理由による之考兄られ，また高酸 素域では掑饂行動が活発であるため，過度に給慨をして しまら傾向があり、これに上り他水槽上り残䬣量が多く なったことも理由の一つとして考えられる。従って，低 酸素域及び高酸素域のいずれる慨料効率を過度に低く見 積もっている可能性がある。

また，飼育実験とは別に，本飼育装置に同様のサイズ の魚を収容し，種々の酸素飽和度の下でその呼吸頻度の 観察を行った。呼吸頻度の測定には同一の個体について 10 回の呼吸運動に要する時間を $8 \sim 10$ 回测定し,この 平均値より 1 分間あたりの呼吸頻度を算出し，酸菜飽和 度との関係を Fig. 4 亿示した。またこの結果についても 酧素飽和度 $10 \%$ 每に区分し，区分每の平均值及び $95 \%$ 信頼限界を示した。。また相対增重率と同様に隣合う3平 均值の移動平均を求め。これらを通る曲線を描き，併世 て Fig. 4 に示した。

この図に見られるように，呼吸頻度には大きな变動は あるものの，全体的には酸素飽和度の低下之共に呼吸頻 度の增加が認められ，特に酸素飽和度 $60 \sim 50 \%$ 程度か らはとの急激な增加が認められる。

\section{考察}

基本的には同様の装置及び方法を用いて飼育を行った コイ, 2) largermouth blackbass, ${ }^{3)}$ ギンザケ, ${ }^{4}$ northern

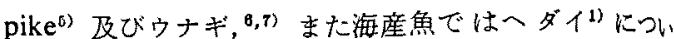

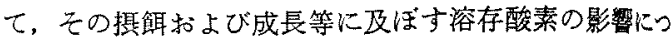
いての報告がある。やや低い值を示した northern pike の例莸除けばいずれの魚種でむ酸素量大略 4 5 ppm, または 40〜 55\% 以下で急激な摃慨率と成長率の低下か 拉きると報告されている。

本研究のア二の場合も上記の魚種とほぼ同样の結果方 得られた。すなわち，酸素飽和度 $45 \%$ 程度を限度とし て，こ水以上では增重率はほぼ一様であるが，これ以下 では酸素量の低下と共に増重率の急激な低下および摃锄 率の低下が認められた。Doudoroffff and Shumway, Davis, ${ }^{, 9} \mathrm{EIFAC}^{10)}$ 等に上り溶存酸素の魚類に及洔寸生 理学的，生化学的，また行動に対する影響についての広 範な総述がなされている。しかし低酸素がどのような作 用機序で魚類の食欲，成長等の低下を惹き起こすのか炕 ついての解明試友た報告にそしい。Swift ${ }^{11)}$ は brown trout について呼吸系による環境水よりの酸素の取り迅 みの能力が增重率を制約するのであるると述へている。

Itazawa $^{12)}$ はニジース、コイおよびウナギについて, 魚類が動脈血中の正常な酸素量を保持することができな くなる環境水の溶存酸素量と增重率の低下をおこす溶存 酸素量とは扰㧍む坟一致することから，動脈血中の酸素 含量の低下が組織に供給される酸菜量の不足を招来する のであ万らとした。Nakanishi and Itazawa ${ }^{18)}$ はコ伲 ついて，溶存酸素の低下は呼吸頻度の增加之心拍数の低 下を伴うことをみており，こ机は動脈血中の酸素量を正 常に保つたるの生理的反応であるとしている。また， Itazawa and Nakanishi' ${ }^{14)}$ は同様にコイについて, 環境 水の溶存酸素量の低下に伴い呼吸頻度の増大が観察さ れ。この呼吸頻度の增大を抗こす環境水の溶存酸素量は 健全な成育が可能な溶存酸素量よりやや高いことを認め ている。本研究のフュの場合も增重率の低下の起こる $45 \%$ 程度々りゃ高い $60 \%$ 程度て呼吸頻度の增加力起 きている。従ってフニでも同様の生理的反応が起きてい たものと想像される。

また, Itazawa and Takeda, ${ }^{14)}$ Takeda and Itazawa ${ }^{15)}$ はコイについて窒菜ガの通気により溶存酸素 を低下させた場合と魚の呼吸により溶存酸素を低下させ た場合では，動脈血中の酸素量を正常に保てなくなる理 境办中の溶存酸素限界值には大きな差異があったことを 報告しており，二酸化炭素の影響の大きいことを指摘し ている。本研究の場合も窒素ガスを用いて溶存酸素の低 下をはかったが，各水槽の排水部に於ける $\mathrm{pH}$ 值はをの 酸素量によらず殆ど差異がなく，従って我槽間に二酸化 炭素の濃度に特別な差はなく，またその濃度す高くはな かったと考えられる。養魚池中でおきる溶存酸素の低下 は主として呼吸によるものであるから，同時に二酸化岸 
素湄度の增大が認められる筈である。しかしながら，本 研究で得た増重率の低下が起きる溶存酸素量 $45 \%$ は,

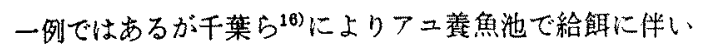
酸素の低下がおき揖飭不良が観察された侮の酸素量とほ ぼ一致与る。養魚上重要と考方られる二酸化炭素の影響 については今後更に椮討する必要があるう。

以上の結果から、フ二養殖に際してその正常な掟䬣・ 成長を期待するためには，飼育我の溶存酸素量は眼和度 45\%以上に保たれるべきであると考えられる。

\section{文献}

1) K. Chiba: Nippon Suisan Gakkaishi, 49, 601610 (1983).

2）千葉健治：淡水研報，15, 35-47 (1970).

3) N. E. Stewart, D. L. Shumway, and P. Doudoroff: J. Fish. Bd. Canada, 24, 475-494 (1967).

4) R. B. Herrman, C. H. Warren, and P. Doudoroff: Trans, Am. Fish. Soc., 91, 155167 (1964).

5) I. R. Adelman and L. L. Smith: P.F. C. 32,
93-96 (1970).

6) 山形陽一, 大中澄美子, 原田增造, 丹羽践： 日水誌, 49,1335-1339 (1983)。

7) S. Rowchai, K. Chiba, and R. Hirano: Nippon Suisan Gakkaishi, 52, 597-607 (1986).

8) P. Doudoroff and D. L. Shumway: FAO Fish. Tech. Paper No. 86, pp. 275.

9) J. C. Davis: J. Fish. Bd. Canada, 32, 22952332 (1975).

10) EIFAC: EIFAC Tech. Paper No. 19, pp. 8 (1973).

11) D. R. Swift: J. Exp. Biol., 38, 596-604 (1961).

12) Y. Itazawa: Nippon Suisan Gakkaishi, 37, 273276 (1971).

13) T. Nakanishi and Y. Itazawa: Report Fish. Res. Lab., Kyushu Univ. 2, 41-52 (1974).

14) Y. Itazawa and T. Takeda: Nippon Suisan Gakkaishi, 45, 323-327 (1979).

15) T. Takeda and Y. Itazawa: Nippon Suisan Gakkaishi, 45, 329-333 (1979).

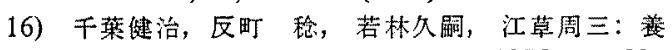
魚用水利用合理化に関する研究，1975, pp. 2935 . 